\title{
INTERVENÇÃO NO DOMÍNIO ECONÔMICO - SOCIEDADE DE ECONOMIA MISTA - ABUSO DO PODER ECONÔMICO
}

\author{
MODALIDADES DE INTERVENÇÃO DO ESTADO NA ORDEM ECO- \\ NÔMICA. REGIME JURIDICO DAS SOCIEDADES DE ECONOMIA MIS- \\ TA. INOCORRENNCIA DE ABUSO DE PODER ECONÔMICO
}

Consulta-me a OPP Petroquímica S.A. acerca dos aspectos constitucionais envolvidos no contrato de associação celebrado com Petrobras S.A., em 12 de setembro de 1997, tendo por objeto projetar, promover, construir e explorar fábricas e empreendimentos no setor petroquímico. À vista das diversas questões suscitadas, o parecer ora apresentado desenvolve-se nos tópicos seguintes:

I. Papel do Estado na ordem econômica. Nota introdutória. Normas constitucionais aplicáveis. Modalidades de intervenção do Estado no domínio econômico: disciplina, fomento e atuação direta;

II. Regime jurídico aplicável à Petrobras no desempenho de suas atividades empresariais $\left(\mathrm{CF}\right.$, arts. $37, \mathrm{XX}$ e 173, $\S 1^{2}$ );

III. Legitimação da Petrobras, como sociedade de economia mista, para atuação no setor objeto do contrato de associaçāo (CF, art. 173);

IV. Nāo aplicabilidade do princípio da licitação ao contratos da natureza do celebrado com a OPP Petroquímica;

V. Inocorrência de Hipótese de abuso do poder econômico por visar à dominação de mercados, à luz dos conceitos constitucionais aplicáveis (CF, art. 173, § 49);

VI. Conclusões.

A seguir, o estudo empreendido, seus fundamentos e conclusões.

\section{O PAPEL DO ESTADO NA ORDEM \\ ECONÔMICA. NOTA INTRODUTÓRIA. \\ AS NORMAS CONSTITUCIONAIS \\ APLICÁVEIS. MODALIDADES DE}

INTERVENÇĀO DO PODER PÚBLICO:

DISCIPLINA. FOMENTO E ATUAÇÃO

DIRETA. AS REFORMAS ECONÔMICAS.

\section{I.1 Nota introdutória}

1. O Estado atravessa, ao longo deste século, três fases bem definidas. A primeira delas, identificada como pré-modernidade ou Estado liberal, exibe um Estado de funçōes reduzidas, confinadas à segurança, justiça e serviços essenciais. É o Estado da virada do século XIX para o XX.' Nele

1 A terminologia pré-modernidade, modernidade e pós-modernidade é empregada em Norbert Reich, Intervenção do Estado na economia (reflexōes sobre a pós-modernidade na teoria jurídica), RDP 94/265.

2 No modelo liberal clássico, o Estado tinha três papéis a cumprir, consoante página clássica de Adam Smith (The Nature and Causes of the Wealth of Nations (The Works of Adam Smith, vol. IV), Londres, 1.811, p. $42: 1^{\circ}$ ) o dever de proteger a sociedade da violência e da invasão por outros Estados: $2^{2}$ ) o dever 
vivia-se a afirmação, ao lado do direitos de participação política, dos direitos individuais, cujo objeto precípua era o de traçar uma esfera de proteçāo das pessoas em face do Poder Público. Estes direitos, em sua expressão econômica mais nítida, traduziamse na liberdade de contrato, na propriedade privada e na livre iniciativa.

2. Na segunda fase, referida como modernidade ou Estado social (welfare state), iniciada com a segunda década deste século, o Estado assume diretamente alguns papéis econômicos, tanto como condutor do desenvolvimento como outros de cunho distributivista, destinados a atenuar certas distorções do mercado e a amparar os contingentes que ficavam à margem do progresso econômico. Novos e importantes conceitos são introduzidos, como os de função social da propriedade e da empresa, assim como se consolidam os chamados direitos sociais, tendo por objeto o emprego, as condiçōes de trabalho e certas garantias aos trabalhadores.

3. A quadra final do século XX corresponde à terceira e última fase, a pós-modernidade, que encontra o Estado sob crítica cerrada, densamente identificado com a idéia de ineficiência, desperdício de recursos, morosidade, burocracia e corrupção. Mesmo junto a setores que, outrora, vislumbravam-no como protagonista do processo econômico, político e social, o Estado perdeu o charme redentor, passando-se a encarar com ceticismo o seu potencial como instrumento do progresso e da transformação. $O$ discurso deste novo tempo é o da desregulamentaçāo, da privatização e das organizações não-governamentais. No plano da cidadania, desenvolvem-se os direitos ditos difusos, caracterizados pela pluralidade indeterminada de seus titulares e pela indivisibilidade de seu objeto. Neles se incluem: a proteção ao meio ambiente, ao con- sumidor e aos bens e valores históricos, artísticos e paisagísticos.

4. Não se deve encobrir, artificialmente, a circunstância de que o Brasil chega à pós-modernidade sem ter conseguido ser nem liberal nem moderno. De fato, no período liberal, jamais nos livramos da onipresença do Estado. A sociedade brasileira, historicamente, sempre gravitou em torno do oficialismo. As bênçãos do poder estatal sempre foram ressalvadas as exceções que confirmam a regra - a razão do êxito ou do fracasso de qualquer projeto político, social ou empresarial que se pretendesse implantar. Este é um traço marcante do caráter nacional, com raízes na colônia, e que atravessou o Império, exacerbou-se na República Velha e ainda foi além. $^{3}$

5. A modernidade teria começado com a Revolução de 30 , institucionalizando-se com a Constituição de 1934 - que abriu um título para a ordem econômica e social - e se pervertido no golpe do Estado Novo, de 1937. Reviveu, fugazmente, no período entre 1946 1964, mas sofreu o desfecho melancólico do golpe militar de 1964. Findo o ciclo ditatorial, que teve, ainda, como apêndice, o período entre 1985-1990, chegou-se à pós-modernidade, que enfrentou, logo na origem, a crise existencial de ter nascido associada ao primeiro governo constitucionalmente deposto da história do país.

6. Passa-se ao largo, por imperativo das circunstâncias, da discussāo sobre as razões que levaram à ampliação da atuaçāo empresarial do Estado Brasileiro, notadamente como alternativa importante à concessão de setores estratégicos à exploraçāo da iniciativa privada estrangeira. Também não será possível estudar o processo crescente de criação de empresas estatais, iniciado tenuemente na década de 40 , ainda durante a $2^{2}$ Guerra Mundial

de estabelecer uma adequada administração da justiça; $3^{2}$ ) o dever de realizar obras públicas e prestar certos serviços públicos que são economicamente desinteressantes para os particulares. Sobre o tema, v. também Alberto Venancio Filho, A intervençāo do Estado no domínio econômico, 1968.

3 Sobre o tema, inclusive com exemplos ilustrativos, v. Luís Roberto Barroso, A crise econômica e o direito constitucional, RF 323/82. Veja-se, também, Raymundo Faoro, Os donos do poder, 1979, vol. I, p. 343 . 
(com marcos importantes como a CSN, Vale do Rio Doce, FNM, CHESF), enredado em amplo debate ideológico na década de 50 (quando foi criada a Petrobras, em 1954) e que se tornou vertiginoso a partir do início do regime militar, em 1964, com a criação, ao longo de duas décadas, de centenas de empresas estatais. Em setembro de 1981, recenseamento oficial arrolava a existência, apenas no plano federal, de 530 pessoas jurídicas públicas, de teor econômico, inclusive autarquias, fundações e entidades paraestatais. ${ }^{\star}$

\section{I.2 Normas constitucionais aplicáveis}

7. A Constituição da República dedica o Título VII à Ordem Econômica e Financeira, tratada em quatro capítulos, dos arts. 170 a 192. Já no art. $1^{2}$ do Texto, todavia, o constituinte fizera a opção inequívoca por um específico modelo econômico, ao inscrever, no inciso IV, dentre os princípios fundamentais do Estado brasileiro, a livre iniciativa. $\mathrm{O}$ princípio, símbolo do Estado liberal e dogma do modo de produção capitalista, revela a opção do constituinte pelo modelo privatista, em contraposição ao sistema do coletivismo econômico, marcado por rígido planejamento estatal e pela apropriação social dos meios de produção. Além de assinalá-lo como princípio fundamental, pareceu bem ao constituinte reiterar o conceito como um princípio setorial, aplicável à atividade econômica, como se vê do caput do art. 170: "A ordem econômica, fundada na valorização do trabalho humano $e$ na livre iniciativa...".

8. Como natural conseqüência do princípio, a legitimidade da atuação estatal na ordem econômica se dá em hipóteses restritas, como nos casos de monopólio público expressamente previstos no Texto (e.g., art. 177) e nas que vêm enunciadas no caput do art. 173, in verbis:

"Art. 173. Ressalvados o casos previstos nesta Constituição, a exploração direta da atividade econômica pelo Estado só será permitida quando necessária aos imperativos da segurança nacional ou a relevante interesse coletivo, conforme definidos em lei".

9. O princípio da livre iniciativa, do ponto de vista jurídico, pode ser decomposto em alguns elementos que lhe dão conteúdo, todos eles devidamente desdobrados no texto constitucional. Pressupõe, ele, em primeiro lugar, a existência de propriedade privada, isto é de apropriação particular dos bens e dos meios de produção (CF, arts. 50, XXII e 170, II). De parte isto, integra, igualmente, o núcleo da idéia de livre iniciativa a liberdade de empre$s a$, conceito materializado no parágrafo único do art. 170: "É assegurado a todos o livre exercício de qualquer atividade econômica, independentemente de autorizaçāo dos órgãos públicos, salvo nos casos previstos em lei". Em terceiro lugar situa-se a liberdade de lucro, lastro para a faculdade de o empreendedor estabelecer os seus preços, que hão de ser determinados, em princípio, pelo mercado, por meio de "livre concorrência", locução obrigada no art. 170, IV. E, por fim, é da essência do regime de livre iniciativa a liberdade de contratar, decorrência lógica do princípio da legalidade, fundamento das demais liberdades, pelo qual ninguém será obrigado a fazer ou deixar de fazer alguma coisa senão em virtude de lei (CF, art. 5o, II).

10. Note-se, todavia, que o princípio da livre iniciativa é condicionado por fins públicos previstos no próprio texto da Constituiçāo, como o dever do Estado de promover o bem de todos (art. 3․ IV) e a justiça social (art. 170, caput). Daí virem prevista na Carta diversas medidas destinadas a neutralizar ou reduzir as distorções que possam advir do abuso da liberdade de iniciativa. Diogo de Figueiredo sistematiza-as com apuro:

"O princípio da liberdade de iniciativa tempera-se pelo da iniciativa suplementar do Estado; o princípio da liberdade de empresa corrige-se com o da definiçāo da função social da empresa; o princípio da liberdade de 
lucro, bem como o da liberdade de competição, moderam-se com o da depressão do poder econômico; o princípio da liberdade de contratação limita-se pela aplicação dos princípios de valorização do trabalho e da harmonia e solidariedade entre as categorias sociais de produção; e, finalmente, o princípio $\mathrm{da}$ propriedade privada restringe-se com o princípio da funçāo social da propriedade". 5

\section{I.3. Modalidades de intervenção} do Poder Público: disciplina, fomento e atuação direta

11. É possível sistematizar, por diferentes critérios, as formas de intervenção do Estado no domínio econômico. Há autores que se referem a intervenção (a) regulatória, (b) concorrencial, (c) monopolista e (d) sancionatória. ${ }^{6}$ Outros classificam-nas em (a) poder de polícia, (b) incentivos à iniciativa privada e (c) atuação empresarial. ${ }^{7}$ A primeira classificaçāo será retomada mais adiante. Por ora, cabe explorar, com brevidade, a segunda, da qual decorrem três conjuntos de mecanismos de intervenção estatal no domínio econômico: pela disciplina, pelo fomento, pela atuação direta.

12. O Poder Público interfere com a atividade econômica, em primeiro lugar, traçando-lhe a disciplina, e o faz mediante a edição de leis, de regulamentos e pelo exercício do poder de polícia. De fato, o Estado exerce competências normativas primárias e edita normas decisivas para o desempenho da atividade econômica, algumas com matriz constitucional, como, por exemplo, o Código do Consumidor (art. 5ํ, XXXII), a lei de remessa de lucros (art. 172), a lei de repressão ao abuso do poder econômico (art. 173, $\S 4^{2}$ ), dentre inúmeras outras. Exerce, ademais, competências normativas de cunho administrativo, edi- tando decretos regulamentares, resoluçōes, deliberações, portarias, algumas em domínios relevantíssimos como a política de crédito e a política de câmbio, em meio a muitas outras. Por fim, desempenha, também, o poder de polícia, restringindo direitos e condicionando o exercício de atividades em favor do interesse coletivo (e.g., polícia ambiental, sanitária, fiscalizaçāo trabalhista).

13. De outra parte, o Estado interfere no domínio econômico por via do fomento, isto é, apoiando a iniciativa privada e estimulando determinados comportamentos. Assim, por exemplo, através de incentivos fiscais, o Poder Público promove a instalação de indústrias ou outros ramos de atividade em determinada região. Do mesmo modo, a elevação ou redução da alíquota de impostos - notadamente os que têm regime excepcional no tocante aos princípios da legalidade e anterioridade, como IPI, importação, IOF — é decisiva na expansão ou retração de determinado segmento da economia. Igualmente relevante, no fomento da atividade econômica, é a oferta de financiamento público a determinadas empresas ou setores do mercado, mediante, por exemplo, linha de crédito junto ao BNDES.

14. Por fim, o Estado interfere, ainda, na ordem econômica, mediante atuação direta. Aqui, todavia, é necessário distinguir duas possibilidades: (a) a prestação de serviços públicos; e (b) a exploração de atividades econômicas. Não há necessidade, nesta instância, de percorrer, com maior grau de detalhamento, aspectos orgânicos e funcionais da Administração Pública. Basta o registro de que os serviços públicos podem ser prestados diretamente, pelos órgãos despersonalizados integrantes da Administração, ou indiretamente, por entidades com personalidade jurídica própria.

15. $\mathrm{Na}$ prestação indireta abrem-se duas possibilidades: pode o Estado constituir pes-

5 Diogo de Figueiredo Moreira Neto, Ordem econômica e desenvolvimento na Constituiçäo de 1988, 1989 , p. 28.

6 Diogo de Figueiredo Moreira Neto, Curso de direito administrativo, 1996, p. 365.

7 Celso Antonio Bandeira de Mello, Curso de direito administrativo, 1996, pp. 434/5. 
soas jurídicas públicas (autarquias e fundaçōes públicas) ou privadas (sociedades de economia mista e empresas públicas) e, mediante lei (CF, art. 37, XIX), outorgar a tais entes a prestação do serviço público, seja de educação, água, eletricidade ou qualquer outro. Ou pode, por outro lado, delegar à iniciativa privada, mediante contrato ou outro ato negocial, a prestação do serviço. Serve-se aí o Estado de figuras jurídicas como a concessão e a permissão. Mais recentemente, têm sido concebidas diferentes formas de delegação, identificadas genericamente como terceirização, que incluem espécies negociais como a franquia e o contrato de gestão, dentre outros. O caput do art. 175 provê sobre o tema:

"Art. 175. Incumbe ao Poder Público, na forma da lei, diretamente ou sob regime de concessão ou permissão, sèmpre através de licitação, a prestação de serviços públicos".

16. A exploraçāo da atividade econômica, à sua vez, não se confunde com a prestação de serviços públicos, quer por seu caráter de subsidiariedade, quer pela existência de regras próprias e diferenciadas. De fato, sendo o princípio maior o da livre iniciativa, somente em hipóteses restritas e constitucionalmente previstas poderá o Estado atuar diretamente, como empresário, no domínio econômico. Tais exceçōes se resumem aos casos de:

a) imperativo da segurança nacional ( $\mathrm{CF}$, art. 173 , caput);

b) relevante interesse coletivo (CF, art. 173, caput);

c) monopólio outorgado à União (e.g., CF, art. 177).

17. Como se verá no tópico a seguir, a reserva de atividade econômicas à exploraçāo direta e monopolizada da União foi substancialmente alterada e flexibilizada. $E$, quando nāo se trate de monopólio, o Estado deverá atuar diretamente no domínio econômico sob o mesmo regime jurídico das empresas privadas, como deflui do $\S 1^{2}$ do art. 173 da Carta Federal, verbis:

"Art. 173

\$ $1^{\circ}$ A empresa pública, a sociedade de economia mista e outras entidades que explorem atividade econômica pelo Estado sujeitam-se ao regime jurídico próprio das empre- sas privadas, inclusive quanto às obrigações trabalhistas e tributárias."

\subsection{As reformas econômicas}

18. A despeito de seus discutíveis antecedentes, o Estado foi depositário de uma série de expectativas do constituinte de 1988. A verdade, todavia, é que tal modelo de maior intervencionismo estatal nāo resistiu à onda mundial de esvaziamento do Estado como protagonista do processo econômico. Além da simbologia radical da queda do muro de Berlim, a verdade inafastável é que mesmo em países de tradição social-participativa, como Reino Unido e França, houve uma inequívoca redefinição do papel do Estado.

19. No Brasil, o tema ainda vive momentos de efervescência política e jurídica. O Estado, seu tamanho e seu papel, está no centro do debate institucional e ainda mobiliza paixões antagônicas. Discutem-se, simultaneamente, as reformas administrativa, previdenciária e fiscal. Não é irrelevante observar, todavia que a reforma econômica, nas suas dimensões constitucional e legislativa, foi aprovada com índices expressivos de apoio de opiniāo pública e parlamentar, e vem sendo amplamente implementada. Sem embargo de outras cogitaçōes mais complexas e polêmicas, é fora de dúvida que a sociedade brasileira vem crescentemente rejeitando a idéia de um Estado onipotente, arbitrário e ativo - desastradamente ativo - no campo econômico.

20. As reformas econômicas brasileiras envolveram três transformaçōes estruturais que se complementam mas não se confundem. Duas delas tiveram de ser precedidas de emendas à Constituição, ao passo que a terceira se fez mediante a edição de legislação infraconstitucional e a prática de atos administrativos. Confira-se, a seguir, cada uma delas.

21. A primeira transformação substantiva da ordem econômica brasileira foi a extinçāo de determinadas restrições ao capital estrangeiro. A Emenda Constitucional $n^{2}$ 6, de 15.08.95, suprimiu o art. 171 da Constituição, que trazia a conceituaçāo de empresa brasi- 
leira de capital nacional e admitia a outorga a elas de proteção, benefícios especiais e preferências. A mesma emenda modificou a redação do art. 176, caput, para permitir que a pesquisa e lavra de recursos minerais e o aproveitamento dos potenciais de energia elétrica sejam concedidos ou autorizados a empresas constituídas sob as leis brasileiras, dispensada a exigência do controle do capital nacional. $\mathrm{Na}$ mesma linha, a Emenda Constitucional $\mathbf{n}^{\mathbf{2}}$ 7, de 15.08.95, modificou o art. 178, não mais exigindo que a navegação de cabotagem e interior seja privativa de embarcaçōes nacionais e a nacionalidade brasileira dos armadores, proprietários e comandantes e, pelo menos, dois terços dos tripulantes.

22. A segunda linha de reformas que modificaram a feição da ordem econômica brasileira foi a chamada flexibilização dos monopólios estatais. A Emenda Constitucional $\mathrm{n}^{2}$ 5 , de 15.08 .95 , alterou a redação do $\$ 2^{\circ}$ do art. 25 abrindo a possibilidade de os Estadosmembros concederem às empresas privadas a exploração dos serviços públicos locais de distribuição de gás canalizado, que, anteriormente, só podiam ser delegados a empresa sob controle acionário estatal. O mesmo se passou com relação aos serviços de telecomunicações e de radiodifusão sonora e de sons e imagens. É que a Emenda Constitucional $n^{2}$ 8 , de 15.08.95, modificou o texto do dois incisos XI e XII, que só admitiam a concessão a empresa estatal. E, na área do petróleo, a Emenda Constitucional $n^{2} 9$ rompeu, igualmente, com o monopólio estatal, facultando à União Federal a contratação com empresas privadas de atividades relativas à pesquisa $\mathrm{e}$ lavra de jazidas de petróleo, gás natural e outros hidrocarbonetos fluídos, a refinação do petróleo nacional ou estrangeiro, a importaçāo, exportação e transporte dos produtos e derivados básicos de petróleo (outrora vedados pela CF, art. 177 e $\$ 12$, e Lei n² 2.004/51).

23. A terceira transformação econômica de relevo - a denominada privatização - operou-se sem alteração do texto constitucional, com a ediçāo da Lei 8.031, de 12.04.90, que instituiu o Programa Nacional de Privatização. Dentre os objetivos fundamentais do pro- grama incluem-se, nos termos do art. 10, incisos I e IV:

- reordenar a posição estratégica do Estado na economia, transferindo à iniciativa privada atividades indevidamente exploradas pelo setor público;

- contribuir para a modernização do parque industrial do país, ampliando sua competitividade e reforçando a capacidade empresarial nos diversos setores da economia.

24. O programa de desestatização tem sido levado a efeito por mecanismo como a (a) alienaçāo, em leilão nas bolsas de valores, do controle de entidades estatais, tanto as que exploram atividade econômica como as que prestam serviços públicos e (b) a concessão de serviços públicos a empresas privadas. No plano federal já foram privatizadas empresas dos setores petroquímico, siderúrgico, metalúrgico e de fertilizantes, estando em curso a privatização da infra-estrutura, que pressupōe a venda da empresa com a concomitante outorga do serviço público, o que está ocorrendo com as empresas de energia e telecomunicações e com rodovias e ferrovias.

25. Acrescente-se, em desfecho do levantamento aqui empreendido, que, além das Emendas Constitucionais $n^{2} \mathrm{~s}$ 5, 6, 7, 8 e 9, assim como da Lei 8.031/90, os últimos anos foram marcados por uma fecunda produção legislativa em temas econômicos, que inclui diferentes setores, como: energia (Lei 9.247, de 26.12.96), telecomunicaçōes (Lei 9.472, de 16.07.97) e petróleo (Lei 9.478, de 6.08.97), com a criação das respectivas agências reguladoras; modernização dos portos (Lei 8.630, de 25.02.93) e defesa da concorrência (Lei 8.884, de 11.06.94); concessões e permissōes (Leis 8.987, de 13.02.95 e 9.074, de 7.07.95), para citar alguns exemplos.

26. O relato que se vem de concluir, abrangendo a trajetória do Estado brasileiro ao longo das décadas, revela uma tendência nítida nas aspiraçōes da sociedade brasileira. Tal tendência institucionalizou-se pelos mecanismos constitucionais próprios da emenda e da edição de legislação infraconstitucional. A concordância ou discordância em relação a este formato de Estado - fundado, essencialmente, no mercado e na livre concorrência - 
podem e devem ser manifestadas nas instâncias próprias. Não se pode, todavia, negar ou falsear uma ordem legitimamente em vigor. É preciso evitar, aqui, uma das patologias crônicas da hermenêutica constitucional no Brasil: a interpretaçāo retrospectiva, pela qual se procura interpretar o texto novo de maneira a que ele não inove nada, mas, ao revés, fique tão parecido quanto possível com o antigo. ${ }^{8}$ Com argúcia e espírito, Barbosa Moreira estigmatiza a equivocidade desta postura:

"Põe-se ênfase nas semelhanças, corre-se um véu sobre as diferenças e conclui-se que. à luz daquelas, e a despeito destas, a disciplina da matéria, afinal de contas, mudou pouco, se é que na verdade mudou. É um tipo de interpretação em que o olhar do intérprete dirige-se antes ao passado que ao presente, e a imagem que ele capta é menos a representaçāo da realidade que uma sombra fantasmagórica."9

27. No Brasil, com seus paradoxos, mesmo os que defendem a livre iniciativa, a economia de mercado, a globalizaçāo e a nāo intervenção como regra, não resistem, quando em causa própria, a sacrificar o discurso liberal pelo apelo ao socorro estatal. Cabe ao intérprete, todavia, assegurar a supremacia, a unidade e a efetividade das normas constitucionais aplicáveis.

\section{REGIME JURÍDICO APLICÁVEL À PETROBRAS NO DESEMPENHO DE SUAS ATIVIDADES EMPRESARIAIS}

28. A Petrobras S.A., desde a sua criação, tem a forma de sociedade de economia mista. As sociedades de economia mista são pessoas jurídicas de direito privado, instituídas mediante prévia autorização legislativa, com par- ticipação do Poder Público e de capitais privados, e destinam-se à prestação de serviços públicos ou à exploração de atividades econômicas. Revestem a forma de sociedades anônimas, admitem o lucro e sujeitam-se às normas próprias às sociedades mercantis, com eventuais derrogações estabelecidas pelo direito público. ${ }^{10}$

29. A disciplina jurídica das sociedades de economia mista, em geral, e da Petrobras, em particular, é traçada em diferentes diplomas legais. A Constituição Federal prevê, no art. 37, XIX, a exigência de lei específica para sua criação. E, no $\S 1^{2}$ do art. 173 , estabelece o mandamento em torno do qual gravita a presente discussão: o regime jurídico das sociedades de economia mista que exploram atividades econômicas. Confira-se-lhe a diç̧ão:

“Art. 173.

$\S 1^{\varrho}$. A empresa pública, a sociedade de economia mista e outras entidades que explorem a atividade econômica sujeitam-se ao regime jurídico próprio das empresas privadas, inclusive quanto às obrigações trabalhistas e tributárias."

30. Além da Constituição, também o Decreto-lei 200 , de 25.02 .67 , faz referência às sociedades de economia mista, fornecendo um conceito legal e incluindo-as expressamente entre as entidades da Administração Indireta. A lei das sociedades por açōes (Lei 6.404, de 15.12.76), por sua vez, abriu um capítulo específico para esta espécie de sociedade, provendo no art. 235:

“Art. 235. As sociedades anônimas de economia mista estão sujeitas a esta Lei, sem prejuízo das disposições especiais de lei federal."

31. Da conjugaçāo do $\S 1^{\mathrm{Q}}$ do art. 173 da Constituição com o art. 235 da Lei das S.A., poderia o intérprete, fundado na textualidade

8 Sobre este e outros aspectos da interpretação constitucional, v. Luís Roberto Barroso, interpretaçāo e aplicação da Constituição, 1996.

9 José Carlos Barbosa Moreira. O Poder Judiciário e a efetividade de nova Constituiçäo, RF 304/151, 152.

10 Veja-se, por todos, Hely Lopes Meirelles, Direito administrativo brasileiro, 1993, p. 331. 
das normas e na aparência mais óbvia, supor que as sociedades de economia mista sujeitam-se plenamente a um regime de direito privado. Incidiria, contudo, em uma demasia. As sociedades de economia mista integram, como já assentado, a Administraçāo Indireta, e jamais poderão ser equiparadas em toda a extensão a uma sociedade puramente privada. Até porque, se assim fosse, não seria ela uma categoria à parte. Sua disciplina jurídica, portanto, haverá de resguardar princípios e regras de direito público decorrentes do próprio texto constitucional.

32. De fato, contempla a Carta Política uma ampla variedade de normas que se aplicam às sociedades de economia mista, mas não às sociedades privadas em geral. Subordinam-se elas, e.g., aos princípios da legalidade, impessoalidade, moralidade e publicidade inscritos no caput do art. 37, assim como a diversas cláusulas do corpo do artigo; submetem-se, ademais, em matéria orçamentária (art. 165, $\S 5^{\circ}$ ), endividamento (arts. 163, e 52) e prestação de contas (art. 71, II), dentre outras, a comandos de natureza pública. Também se lhes aplica o imperativo do concurso público para contratação de pessoal (art. 37, II), consoante entendimento unânime do Supremo Tribunal Federal."

33. Sem embargo, ao afirmar-se a aplicabilidade de determinados princípios e normas de direito público às sociedades de economia mista, nāo se deve perder de vista que foi precisamente o regime de direito privado que motivou o Poder Público a criar um ente dessa natureza. Em palavras de Hely Lopes Meirelles:

"A sociedade de economia mista ostenta a estrutura e funcionamento da empresa particular, porque isto constitui, precisamente, sua própria razão de ser. Nem se compreenderia que se burocratizasse tal sociedade a ponto de emperrar-lhe os movimentos $e$ a flexibilidade mercantil, com os métodos estatais. "12
34. As normas de direito público, no regime jurídico das sociedades de economia mista, somente se aplicam por exceção e concentram-se em duas áreas: (a) nas suas relaçōes com a pessoa jurídica instituidora e (b) nos seus mecanismos de controle. Estão sujeitas, assim, a procedimentos como a supervisāo ministerial e o controle do emprego de recursos públicos pelo Tribunal de Contas. Tais procedimentos, aliás, não excluem os controles internos da própria sociedade, como, por exemplo, a defesa dos interesses dos acionistas minoritários, sob as regras da legislação societária. Porém, nas suas relaçōes com terceiros, e, sobretudo nas relações com pessoas jurídicas privadas, subordinam-se as sociedades de economia mista às mesmas normas a estas aplicáveis.

35. Calha relembrar, neste passo, que no direito brasileiro existem duas espécies de empresas estatais e, ipso facto, de sociedades de economia mista: as que prestam serviços públicos (de natureza comercial e industrial), cujo lastro constitucional é o art. 175; e as que exploram atividades econômicas, cujo fundamento encontra-se no art. 172. Embora apresentem, como natural, inúmeros traços comuns, há diversidade no regime jurídico de cada uma delas, como se colhe na manifestação de Maria Sylvia di Pietro:

"Diante desses dois dispositivos constitucionais (arts. 173 e 175), pode-se concluir que, quanto ao tipo de atividade e ao regime jurídico, existem duas modalidades de empresas estatais no direito brasileiro:

1. as que desempenham atividade econômica com base no artigo 173 e que se submetem ao regime próprio das empresas privadas; como é a Constituição que estabelece essa regra geral de submissāo ao direito privado, qualquer derrogação a essa regra tem que ter fundamento na própria Constituição; não se aplicam a essas empresas as leis ordinárias que derrogam o direito comum;

11 RTDP 7/260, MS 21.322-DF, Rel. Min. Paulo Brossard.

12 Hely Lopes Meirelles, ob. cit. p. 333. 
2. as que desempenham serviços públicos $\mathrm{e}$ que se submetem ao artigo 175; embora atuem sob regime de direito privado, as derrogaçōes a esse princípio constam não apenas da própria Constituição, como também das leis ordinárias; aqui as derrogaçōes podem ser maiores, porque não encontram a barreira da norma constitucional que determinou a adoção desse regime." 13

36. É certo, assim, que o regime jurídico das sociedades de economia mista exploradoras de atividade econômica é mais próximo ainda do das empresas particulares. De resto, como observou Celso Antônio Bandeira de Mello, é compreensível que para atuar na esfera econômica não necessitem de prerrogativas estranhas à ordem privada - que poderiam ensejar, inclusive, concorrência desleal - e que, por outro lado, precisem de agilidade similar à dos particulares, como condição de sucesso empresarial. É natural, em tais circunstâncias, o fluxo menos intenso de normas de direito público. ${ }^{14}$

37. Nada obstante, não se deve supor que qualquer sociedade de economia mista, como criatura estatal, possa existir descompromissada do interesse público. $O$ que é relevante assinalar, à vista dos comandos constitucionais aplicáveis, é que se estabeleceu que a melhor forma de atender ao interesse público, em certo contexto, era dar a tais sociedades a mobilidade e a liberdade de atuação de uma empresa privada. Não há, assim, uma abdicação do interesse público pela adoção de um regime privado, mas a eleição de um meio específico de atuação para satisfação das finalidades estatais.

38. A aplicação dos conceitos acima desenvolvidos à situação específica aqui versada nāo deixa margem a dúvida quanto à legitimidade da atuação da Petrobras na celebração do contrato, no tocante à sua liberdade de atuação empresarial. Não é passível de con- trovérsia, diga-se desde logo, seu caráter de empresa exploradora de atividade econômica. Ademais, especificamente na área petroquímica, jamais exerceu sequer monopólio. Confira-se, a propósito de seu regime jurídico, o disposto no art. 61 e $\S 1^{10}$ da Lei 9.478 , de 6.08.97, que dispōe sobre a política energética nacional, as atividades relativas ao monopólio do petróleo, dentre outras providências, e que revogou a Lei 2.004 , de 3.10 .53 , abrindo um capítulo específico para a Petrobras:

"Art. 61. A Petróleo Brasileiro S.A. - PETROBRAS é uma sociedade de economia mista vinculada ao Ministério de Minas e Energia, que tem como objeto a pesquisa, a lavra, a refinação, o processamento, o comércio e o transporte de petróleo proveniente de poço, de xisto ou outras rochas, de seus derivados, de gás natural e de outros hidrocarbonetos fluídos, bem como quaisquer outras atividades correlatas ou afins, conforme definidas em lei.

$\S 1^{\text {I }}$ As atividades econômicas referidas neste artigo serão desenvolvidas pela $\mathrm{PE}-$ TROBRAS em caráter de livre competição com outras empresas, em função das condições de mercado, observados o período de transição previsto no capítulo X e os demais princípios e diretrizes desta Lei."

39. A letra da lei, em sintonia necessária com o que dispõe o texto constitucional, não poderia ser mais categórica: a Petrobras desenvolve suas atividades econômicas em caráter de livre competição com outras empresas, em função das condiçōes de mercado. Pois bem: empresas privadas, inclusive as que disputam mercado com a Petrobras, celebram, rotineiramente, pactos de boa fé e pactos de preferência nas parcerias e contratos que celebram. É natural que a Petrobras possa e, eventualmente, deva fazer o mesmo. Impedi-la de atuar sob o mesmo regime das empresas privadas com as quais compete desatende ao interesse público, viola a Constituição e a lei específica que cuida de sua atuação.

13 Maria Sylvia di Pietro, Direito Administrativo, 1996, p. 305.

14 Celso Antônio Bandeira de Mello, ob. cit.. p. 31. 
III - LEGITIMAÇÃO DA PETROBRAS, COMO SOCIEDADE DE ECONOMIA MISTA, PARA ATUAÇÃO NO SETOR OBJETO NO CONTRATO DE ASSOCIAÇÃO (CF, art. 173)

40. A Constituição Federal de 1988 consagrou, no capítulo dedicado à ordem econômica e financeira, o regime da livre iniciativa e da livre concorrência, de modo a conferir à iniciativa privada a prerrogativa de organizar os fatores de produção. Cabe, deste modo, ao setor privado o papel principal na busca do desenvolvimento econômico e da produção de riquezas. Ao Estado, de outro lado, incumbe, essencialmente, a tarefa de exercer a função fiscalizatória e regulatória das atividades econômicas, coibindo abusos que possam advir do exercício anormal da atividade empresarial.

41. Sem embargo, compete ao Estado, em ocasiōes excepcionais, explorar ele mesmo, ou através de empresas que constitui e controla, a atividade econômica. Trata-se do princípio da subsidiariedade, segundo o qual o Estado deve se abster de criar entidades para concorrer com o setor privado fora de hipóteses de extrema relevância. O princípio da abstençāo dele decorrente vem consagrado desde a Constituição de 1946 (art. 146), com base na qual foi editada a Lei $n^{2} 2.004 / 51$, que autorizou a criação da Petrobras. O princípio foi mantido na Carta de 1967 (arts. 157 e 163), bem como na Emenda Constitucional n 01/69 (arts. 163 e 170), sendo esta, também, a inteligência do artigo 173 da Constituição em vigor, que somente permite a atuação direta do Estado na exploração da atividade econômica quando necessária aos imperativos da segurança nacional ou a relevante interesse coletivo.

42. Estes, portanto, os limites batizadores traçados pelo legislador constituinte.

43. Não é fácil, para o intérprete constitu- cional, definir, com precisão, o que seja segurança nacional ou relevante interesse coletivo. Note-se que, no particular, tal atribuição foi deferida, primeiramente, ao legislador ordinário, ao qual sempre se reconheceu uma certa amplitude de julgamento quanto à conveniência e oportunidade da atividade econômica pública. ${ }^{15} \mathrm{O}$ certo é que a fluidez de tais termos projetam-nos no campo dos conceitos jurídicos indeterminados ${ }^{16}$, a serem delineados em cada caso concreto. Não comportam eles, por via de consequiência, definição linear e genérica que lhes confira sempre a mesma identidade e feição.

44. Apesar da excepcionalidade atribuída ao exercício de atividades econômicas pelo Estado, o fato é que circunstâncias diversas levaram à ampliação de sua atuação nessa área, com a criação, ao longo dos anos, de inúmeras empresas estatais. Mais recentemente, no fluxo de uma tendência mundial, o Estado vem redefinindo seu papel, sob o discurso da concentração de esforçoso em áreas específicas e limitadas. Como decorrência, tem-se restaurado em diversos setores da economia, já sem a presença do Poder Público atuando empresarialmente, mecanismos normais de mercado.

45. Neste contexto, foi criado o Programa Nacional de Desestatização, através da Lei $n^{\Omega}$ 8.031 de 12.04 .90 , alterada pela Medida Provisória n 1.481 -52 de 08.08.97, que foi, posteriormente, convertida na Lei $\mathrm{n}^{2} 9.491$, de 9.09.97. Tal programa tem por escopo reduzir a participaçāo do Estado como agente econômico através, principalmente, da privatizaçāo de empresas por ele controladas. A lei, em última análise, deu poderes ao Executivo para reavaliar e redefinir, com grande amplitude, a cláusula constitucional do "relevante interesse coletivo". A inclusão de empresas no programa de desestatização dá-se por mero decreto. A lei, todavia, conquanto abrangente, estabeleceu determinados limites e abriu exceções expressas.

15 Caio Tácito, ob. cit., p. 3 .

16 Sobre o tema, v. José Carlos Barbosa Moreira, Regras de experiência e conceitos jurídicos indeterminados, RF 261/13. 
46. De fato, reconhece o texto legal, de forma expressa, que determinadas empresas desempenham papel estratégido na economia brasileira, pelo que deveriam estar excluídas do programa de desestatizaçāo. Nesta linha, dispôs o art. $3^{2}$ da Lei $n^{2}$ 8.031, de 13.04.90:

"Art. 3". As transferências de açōes de propriedade da Uniäo, representativas do capital social da Petróleo Brasileiro S.A, continuarão a reger-se pelo disposto nos arts. 11 e 18 da Lei n 2.004, de 03 de outubro de 1953."

47. Sobre o tema, averbou José Edwaldo Tavares Borba:

"Como empresa, a PETROBRAS permanecerá excluída do processo de privatização, e a transferência das ações de seu capital, de propriedade da Uniāo, continua adstrita ao disposto na Lei $n^{\complement} 2.004 / 53$. Nessas condições, $51 \%$ do capital deverão permanecer na titularidade da União. As demais ações poderão ser alienadas, inclusive dentro do processo de privatização." 17

48. Tal entendimento do legislador não se modificou após a revisão das normas atinentes ao Programa. $\mathrm{O}$ artigo $2^{2}, \S 2^{2}$ da Lei $n^{2}$ 9.491/97, prevê expressamente:

"Art. 2Q-Poderão ser objeto de desestatização, nos termos desta lei:

$\$ 2^{\varrho}$ - Aplicam-se os dispositivos desta Lei, no que couber, às participações minoritárias diretas e indiretas da União no capital social de quaisquer outras sociedades e às ações excedentes à participação acionária detida pela Uniāo representativa do mínimo necessário à manutenção do controle acionário da Petróleo Brasileiro S.A. - PETROBRAS, nos termos do Artigo 62 da Lei $n^{\circ} 9.478$, de 06.08.97."

49. Permanece, assim, com a União o controle acionário da empresa, o que importa em reconhecer mantido o caráter estratégico que ela desempenha no contexto de economia nacional. De certo modo, foram revistos todos os fundamentos jurídicos que alicerçavam as empresas estatais existentes, concluindo-se que somente algumas delas - e a Petrobras inclui-se neste rol - apresentavam-se dentro dos parâmetros constitucionais anteriormente traçados. Fica claro que a exclusão expressa da Petrobras do Programa Nacional de Desestatização resulta de uma decisão política que reconhece a legitimação da entidade para explorar atividades econômicas à vista de um relevante interesse coletivo.

50. Com o advento da Emenda Constitucional $\mathrm{n}^{2} 9$, de 09.11.1995, que alterou o artigo 177 da Constituição Federal, passou-se a admitir que outras empresas viessem a atuar no setor de petróleo e seus derivados, instaurando-se a livre competição no mercado. A Petrobras passou, assim, a exercer uma intervençāo concorrencial no domínio econômico e não mais uma intervenção monopolística. Ora bem: inserindo-se no objetivo legal da Petrobras a atuação no setor petroquímico, como se depreende do art. 61 da Lei 9.478/97, já transcrito, nada há de atípico que venha a celebrar contrato como o que é objeto do presente parecer, estabelecendo uma associação com a OPP Petroquímica S.A.

\section{IV - A NĀO APLICABILIDADE DO PRINCÍPIO DA LICITAÇÃO AO CONTRATO EM QUESTÃO (ART. 37, XXI)}

51. Licitação, conforme conhecimento convencional, é o procedimento pelo qual a Administração seleciona a proposta mais vantajosa, dentre candidatos devidamente habilitados, e fundada em julgamento objetivo, para posterior contrataçāo. $O$ tema passou a ser tratado em sede constitucional a partir de 1988. O art. 22, XXVII, institui a competência privativa da União para legislar sobre normas gerais de licitaçōes e contratações. Os demais dispositivos - arts. 37, XXI e 175, caput definem os objetos que se submetem ao princípio da licitação. ${ }^{18}$ Este último dispositivo impōe a necessidade de licitação para as con-

17 José Edwaldo Tavares Borba, Sociedade de economia mista e privatização, 1997, p. 44. 
cessōes e permissões de serviços públicos. Já o inciso XXI do art. 37, por sua relevância para a hipótese aqui versada, merece atenção especial. Confira-se a literalidade de sua dicção:

"Art. 37

$X X I$. ressalvados os casos especificados na legislação, as obras, serviços, compras e alienações serão contratados mediante processo de licitaçāo pública...".

52. Fixando o que se deve contratar, mediante licitação, escreveu Hey Lopes Meirelles:

"A finalidade precípua da licitação será sempre a obtenção de seu objeto - uma obra, um serviço, uma compra, uma alienação, uma locação, uma concessão ou uma permissão - nas melhores condiçōes para o Poder Público." 19 (Grifo acrescentado)

53. Tais comandos constitucionais, enfim, têm por objetivo resguardar o interesse público nas contrataçōes da Administração direta e indireta e atuam como fatores indispensáveis para a eficiência e moralidade dos negócios administrativos. São atividades instrumentais, nas quais o legislador não deixa margem de escolha - já que a regra é a licitação.

54. É bem de ver, no entanto, que o inciso XXI do art. 37 não se aplica ao contrato de associação celebrado entre a OPP e a Petrobras, por razões que se cumulam. Em primeiro lugar porque não se enquadra ele na tipificação constitucional, uma vez que não tem por objeto obra, serviço, compra ou alienação. De parte esta leitura de cristalina clareza do dispositivo, outros fundamentos, de cunho sistemático e teleológico, corroboram a tese da inaplicabilidade do princípio licitatório à espécie.

55. Sem desprezo ao princípio da moralidade e com ênfase no dever de eficiência imposto ao administrador público, hipóteses existem em que, precisamente para cumprir a Constituiçāo, nāo se deverá proceder à licita- ção, sob pena de tolher-se a Administração e frustar seus fins. Admite-se, assim, na própria cláusula inicial do inciso XXI do art. 37, situações de contratação direta, desde que especificadas na legislação. A Lei 8.666, de 21.06.93, integra o comando constitucional enunciando as hipóteses em que é possível a dispensa de licitação - figura legal que permite ao administrador, nos casos preestabelecidos, deixar de lado a realização de certame público, por conveniência e oportunidade (art. 24) - $\mathrm{e}$ as de inexigibilidade de licitação, por inviabilidade de competição (art. 25).

56. Exposta a principiologia e o regramento aplicáveis, é fora de dúvida que nāo se poderia cogitar da imperatividade de realização de licitação em uma atividade-fim, de natureza empresarial, fruto da atuação constitucionalmente admitida do Estado no domínio econômico. Remarque-se, nesse passo, que tal atividade de exploração econômica é regida pelo $\S 1^{\circ}$ do art. 173, já estudado anteriormente, e que estabelece, nas circunstâncias, que as relações da Petrobras com terceiros se regem por regras de direito privado. Vale dizer: como sociedade de economia mista que celebrou um negócio jurídico de natureza comercial com uma empresa privada, sujeita-se a Petrobras, salvo as exceçōes constitucionais que aqui não se aplicam, à mesma legislação que rege atos idênticos praticados por sociedades comerciais.

57. Já se viu, anteriormente, que as sociedades de economia mista são regidas pela lei das sociedades por ações (Lei 6.404, de 15.12.76, art. 235). Assinalou-se, também, que a Petrobras, desde a sua criação, reveste a natureza de sociedade de economia mista (Lei 2.004/53, arts. 11 e 18), condição ratificada pela Lei 9.478 , de 6.08.97, em seu art. 61. Assim criada e mantida, a Petrobras firmou com a $O P P$ contrato de a associação cujo objeto é a reunião de recursos e esforços para promover, construir e explorar atividades me-

18 Embora não mencionada na Lei Maior, a concessāo e a autorização para exploração de bens mencionados no art. 176. $\$ 1^{\circledR}$. CF, também, como regra, são precedidas de licitaçāo, na forma da lei específica.

19 Hely Lopes Meirelles, Licitação e contrato administrativo, 1996, p. 42. 
ramente econômica, dentro de um sistema de economia de mercado e, no caso, de um mercado de dimensāo internacional. Aqui, não resta dúvida de que se está diante de objetivo social da própria Petrobras, razão de sua existência, e que, por tal motivo, não pode se submeter à regra de licitação.

58. Atente-se: conforme consignado expressamente no contrato de associação, em sua parte introdutória, é diretriz da política econômica nacional a criação de condições para a reestruturação competitiva de setores industriais básicos, dentre os quais se inclui o petroquímico, com o objetivo de modernizar e fortalecer a competitividade nacional em nível internacional. Diante de tais premissas, a formaçāo de parcerias pela Petrobras se afigura indispensável e, notadamente, prescinde de licitação. Aliás, apoiando e conferindo legalidade e moralidade à iniciativa da formação destas parcerias, a Lei 9.478 , de 06.08.97 (que dispõe sobre a política energética nacional, as atividades relativas ao monopólio do petróleo, institui o Conselho $\mathrm{Na}$ cional de Política Energética e a Agência Nacional do Petróleo e dá outras providências) estabeleceu, em seu artigo 63:

“Art. 63. A Petrobras e suas subsidiárias ficam autorizadas a formar consórcios com empresas nacionais ou estrangeiras, na condição ou não de empresa líder, objetivando expandir atividades, reunir tecnologias e ampliar investimentos aplicados à indústria do petróleo".

59. Note-se, assim, que a própria Lei 9.478/97 não se refere à necessidade de licitação para parcerias ou associações, contrariamente ao que se passa em relação aos contratos de concessão - art. 23 -, ou para aquisição de bens e serviços - art. $67 . \mathrm{O}$ contrato em tela se afigura espécie de consórcio comercial, resultante de um contrato entre sociedades, para a execução de diversos empreeendimentos na área petroquímica. Aliás, a própria cláusula $1^{\mathrm{a}}$ já menciona a reuniāo de esforços para a realização de obra comum, característica primordial dos consórcios.
60. Cuida-se, no caso, de formação de contrato similar ao ato complexo do direito administrativo, que se manifesta através de uma única conta vontade, formada pela reuniāo de manifestaçōes de duas ou mais pessoas. Sua base legal encontra-se lançada no artigo 278 da Lei 6.404/76, in verbis:

"Art. 278. As companhias e quaisquer outras sociedades, sob o mesmo controle ou não, podem constituir consórcio para executar determinado empreendimento, observado o disposto neste capítulo."

61. Note-se, então, que a Petrobras realiza uma associação, uma parceria comercial, que visa à exploraçāo econômica através da formação da Companhia Petroquímica Paulista com vistas a objetivo comum, tudo com fulcro no art. $173, \S 1^{2}$ da Constituição Federal e art. 235 , c/c 278 da Lei 6.404/76. O negócio jurídico é de legitimidade plena e a exigência de licitação uma total impertinência constitucional e legal. Aprofunde-se um pouco mais o conhecimento sobre esta espécie de instrumento comercial com a passagem doutrinária de Amador Paes de Almeida, a seguir transcrita:

“Consórcio, etimologicamente, significa união, combinação, associaçāo.

No sentido que lhe empresta a atual legislação sobre sociedade anônima, consórcio é uma forma de associação de empresas com o objetivo de desenvolver determinados empreendimentos. $" 20$

62. O instituto em questão não é novo no Direito e vem sendo utilizado em diversos países, como forma de cooperação tipificada, e tendo por objetivo a penetraçāo em mercados internacionais, tal qual ensinam Santos, Gonçalves e Leitão Marques:

"Com a consagração da figura do consórcio, a lei portuguesa (Decreto-Lei n $n^{2} 231 / 81$, de 28 de julho) adaptou uma concepção de empresa comum não societária (unincorporated joint-venture) (47). Tal não significa que esteja excluída a possibilidade de criação de incorporated joint ventures, as quais se constituirão sob a forma de sociedades co- 
merciais (a forma mais frequientemente utilizada tem sido a de sociedade por quotas).

O consórcio é definido como um contrato pelo qual duas ou mais pessoas, singulares ou colectivas, que exercem uma actividade econômica, se obrigam entre si. de forma concertada, a realizar uma certa actividade ou a efectuar uma certa contribuição com o fim de prosseguir um dos seguintes objetivos: - realização de actos, materiais ou jurídicos, preparatórios quer de um determinado empreendimento, quer de uma actividade contínua; execução de determinado empreendimento, fornecimento de bens (...) produzidos por cada um dos membros do consórcio: pesquisa ou exploração de recursos naturais; produção de bens que possam ser repartidos, em espécie, entre os membros do consórcio (arts. $1^{o}$ e 29)." 21

63. Em uma associação que tal, nāo se pode prescindir da affectio societatis, elemento indissociável desse contrato, que identifica, em meio a outros aspectos, a afinidade entre as partes e a motivaçāo pela qual decidem somar esforços para produzir um resultado de interesse comum. Sobre o tema, veja-se a liçāo de Rubens Requião:

"Esse elemento característico do contrato societário é altamente útil na prática da vida comercial, para distinguir a sociedade de outros tipos de contrato, que tendem a se confundir, aparentemente, com a sociedade de fato presumida. O conceito é subjetivo, o elemento é intencional, e se deve perquirir dos reflexos aparentes e exteriores, se a intenção do agente foi de unir seus esforços para obter resultados comuns, que isoladamente nāo seriam tão plenamente conseguidos."

64. Por fim, pode-se afirmar que a afinidade que se pretende com a associaçāo é que vai definir a melhor parceria, e não licitação, que, frise-se, não é o único meio de se atingir a moralidade e a eficiência na contrataçāo. No caso. ocorreria uma espécie de inexigibilidade de licitação, já que há inviabilidade de se aferir, com os critérios objetivos inerentes à licitação, a proposta que melhor se adequará, ou terá maior afinidade com o que se pretende em face das diretrizes traçadas. Afinal, só existe viabilidade no certame se a competiçāo envolve homogeneidade de bens e parâmetros objetivos de aferição.22

65. Confira-se, nessa linha, a liçāo de $\mathrm{Hel}$. Lopes Meirelles, dando conta de situação em que a própria instauração de licitação, dependendo do caso, pode afrontar o propósito das operaçōes, e, consequientemente, os princípios inerentes à Administração Pública:

"Diante do exposto, verificando-se a hipótese de inviabilidade de competiçāo, se o responsável pela contrataçāo determinar a realização de qualquer modalidade licitatória. estará afrontando os princípios da legalidade e da finalidade, examinados sucintamente no item I, acima." 23

66. Tal como ocorre nos convênios e consórcios administrativos, a união de esforços e objetivos idênticos, a confiança e a lealdade recíproca não são licitáveis, via de regra. $O$ tema nāo é controvertido. Confira-se, a respeito, a posiçāo de Maria Sylvia di Pietro:

"Enquanto os contratos abrangidos pela Lei $n^{0} 8.666$ são necessariamente precedidos de licitação - com as ressalvas legais - no convênio não se cogita de licitação, pois não há viabilidade de competição quando se trata de mútua colaboração, sob variadas formas, como repasse de verbas, uso de equipamentos, de recursos humanos, de imóveis, de "know-how". Não se cogita de preços ou de remuneração que admita competição. "24

67. E ainda Maria Garcia:

“h) por final: tratando-se de acordos de cooperação, ou de colaboração, de unicidade e

21 Antonio Carlos Santos, Maria Eduarda Gonçalves e Manuel Leitão Marques, Direito económico, 1993 , p. 327 .

22 Rubens Requiāo, Curso de direito comercial. 1995, 1ำ vol., p. 289.

23 Hely Lopes Meirelles, Estudos e pareceres de direito público, 1991, v. II, p. 23 e 24.

24 Maria Sylvia Zanella Di Pietro, Temas polêmicos sobre licitaçôes e contratos, 1995, $2^{\mathbf{a}}$ ed.. p. 216. 
não de duplicidade, fica afastada a necessidade de licitação, ou concorrência: ou porque a finalidade seja tāo específica, direta e determinada que impossibilite a participação de outrem ou porque a participação de outra pessoa não esteja vedada, em razão da finalidade do acordo, que permite outros partícipes no convênio." 25

68. Conclui-se, assim, à vista dos dispositivos constitucionais e legais aplicáveis, e pela própria natureza das coisas, que nāo é exigível e, normalmente, não é possível a realização de licitação para seleção de parceiro em um consórcio ou associação.

\section{V - A INEXISTÊNCIA DE ABUSO DO PODER ECONÔMICO}

69. Para os fins aqui visados, deve-se confrontar o negócio jurídico celebrado pelos contratantes como o $\$ 4^{\circ}$ do art. 173 da Constituiçāo Federal, que cuida do tema do abuso do poder econômico, em dispositivo assim redigido:

“Art. 173

$\S 4^{\ell}$ A lei reprimirá o abuso do poder econômico que vise à dominação dos mercados, à eliminação da concorrência e ao aumento arbitrário dos lucros".

70. A cláusula do contrato de associação entre a $O P P$ e a Petrobras que sucitou controvérsias foi a oitava, cuja redação é a seguinte:

\section{"CLÁUSULA OITAVA - CONFLITOS DE INTERESSES}

Respeitados os acordos e negócios de produção de produtos petroquímicos existentes de que participem, as partes evitarão participar, isoladamente, de novos investimentos ou negócios que sejam conflitantes com os empreendimentos petroquímicos organizados nos termos deste contrato, e com esse objetivo cada parte:

a) antes de promover o e estudo e planejamento de outros projetos, manterá negocia- ções de boa fé com a outra parte visando a evitar conflitos de interesses:

b) antes de contratar participação em projeto não organizado nos termos desse contrato, oferecerá à outra parte oportunidade de participar do projeto nas mesmas condições da ofertante; se a parte que receber a oferta nāo aceitar a oferta, a ofertante ficará livre para prosseguir com o projeto sem a participação da outra parte".

71. Não é difícil demonstrar que o ajuste não se enquadra na tipificação constitucional, que por não ter havido abuso de poder econômico, quer porque não visa à dominação dos mercados, à eliminação da concorrência e ao aumento arbitrário de lucros.

72. Antes de proceder ao exame objetivo que revelará a inexistência de abuso do poder econômico, cabe demonstrar, de plano, a ausência do elemento subjetivo, isto é, da intenção de qualquer comportamento neste sentido. De fato, a leitura da cláusula transcrita e do teor integral do contrato revela que a motivação das partes foi evitar o conflito de interesses, preservando a afinidade e a fidelidade que devem caracterizar as sociedades $\mathrm{e}$ parcerias comerciais. Dois elementos de interpretação - um constitucional e outro infraconstitucional - são úteis no equacionamento do tema, consoante se desenvolve abaixo.

73. A livre iniciativa, como já observado, é um princípio constitucional, duplamente referido na Lei Maior (arts. 1으. IV e 170, caput). A interpretação constitucional, conforme doutrina corrente, deve ter como ponto de partida e como diretriz de todo o raciocinio os princípios constitucionais, que são os valores maiores escolhidos pelo constituinte ao elaborar a nova ordem. Dentre estes princípios destacam-se os princípios fundamentais, que contêm as decisōes políticas estruturais do Estado, os quais, por sua relevância, devem permear a compreensão de todo o sistema jurídico. Consoante averbamos em outro estudo: 
"O ponto de partida do intérprete há que ser sempre os principios constitucionais, que sāo o conjunto de normas que espelham a ideologia da Constituição, seus postulados básicos e seus fins. Dito de forma sumária, os princípios constitucionais são as normas eleitas pelo constituinte como fundamentos ou qualificações essenciais da ordem jurídica que institui. A atividade de interpretação da Constituição deve começar pela identificação do princípio maior que rege o tema a ser apreciado, descendo do mais genérico ao mais específico, até chegar à formulação da regra concreta que vai reger a espécie. "26

74. Pois bem: a livre iniciativa, que é a norma maior regente da espécie, é princípio fundamental do Estado brasileiro, inscrito no

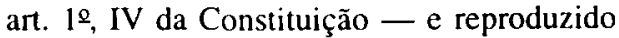
como um princípio setorial da ordem econômica no art. 170, caput - que tem como conteúdo jurídico específico a liberdade de contratar. Porque assim é, a interpretação constitucional deve fundar-se em tal pressuposto, não sendo consentâneo com a boa técnica que se procure minimizar o alcance de um princípio fundamental, nem que se presuma algo em sentido antagônico ao seu conteúdo. E mais: dentre alternativas possiveis de interpretação, deve o intérprete potencializar a aplicação de um princípio fundamental. Isto significa que para frustar-se a efetivação do princípio da livre iniciativa é preciso estar escudado em exceçāo que a própria Constituição estabeleça e de cuja ocorrência se faça prova cabal e inequívoca.

75. No plano infraconstitucional, a regra, em direito privado, é a da autonomia da vontade (em contraposição ao princípio da legalidade, que rege o direito público infraconstitucional), sendo princípio basilar da interpretação dos negócios jurídicos a busca da intenção das partes (CC, art. 85). Ainda neste plano volitivo, dispõe o Código Civil no art. 131:
"Art. 131. As declarações constantes de documentos assinados presumem-se verdadeiras em relação aos signatários".

76. Em desfecho do argumento, cabe reconhecer que a liberdade de iniciativa e a autonomia contratual no modelo de Estado democrático de direito acolhido pela Constituição Federal de 1988 estão condicionadas por outros valores relevantes, como a promoção do desenvolvimento e da justiça social, assim como a defesa do consumidor. Por tais razões, admite-se o intervencionismo estatal, dentre outras hipóteses, para reprimir o abuso de poder econômico. Mas não se deve ignorar o relato da norma inscrita no $\$ 4^{2}$ do art. 173 , em cuja dicção se exige o específico elemento subjetivo da intenção das partes ("... que vise à...") em dominar mercados, eliminar a concorrência ou aumentar arbitrariamente os lucros, admitindo, com isso, inclusive, a puniçāo da tentativa. ${ }^{27}$

77. Ora bem: à luz dos princípios e regras constitucionais aplicáveis, assim como do Direito infraconstitucional e do teor do instrumento contratual aqui comentado, a presunção é a de que nāo existe qualquer intenção de dominação do mercado, de eliminação da concorrência ou de aumento arbitrário de lucros. Calha assinalar, ademais, que a ordem jurídica não é infensa à proteção de idéias, metas, planos e sistemas, assim como não repudia cláusula de não competição entre parceiros ou adquirentes de negócios. ${ }^{28}$. Aliás, especificamente no setor econômico do petróleo, não são incomuns as alianças estratégicas entre empresas, assim na pesquisa e na lavra como na produção de derivados.

78. Passando ao plano objetivo, é relativamente singela a tarefa de demonstrar a inexistência de abuso de poder econômico no caso sob exame. Como natural, não se está aqui lidando com a acepção leiga de poder econô-

26 Luís Roberto Barroso, Interpretação e aplicação da Constituição, 1996, p. 141.

27 Embora o dispositivo constitucional seja claro, data vênia, quanto à exigibilidade da intenção, tal entendimento não é pacífico. Cf. Fábio Ulhoa Coelho, Direito antritruste brasileiro, 1995, p. 55, no sentido de que deve ser pesquisado o resultado.

28 V. Hermano Duval, Concorrência desleal. 1976, p. 310-3. 
mico, hipótese em que seria inegável a sua presença em uma associaçāo entre duas empresas do porte da OPP e da Petrobras. Em sentido técnico, todavia, como utilizado na Constituição e na legislação antitruste, poder econômico pode ser conceituado como a possibilidade de ditar preços em um mercado relevante, sem levar em conta a atuação dos competidores ou dos custos envolvidos com a produção. $\mathrm{O}$ que deve ser considerado é a capacidade de impor preços e não a parcela detida no mercado. Esse poder de fixar preços compreende a possibilidade de fazê-lo arbitrariamente e, assim, fora do razoável. Nesta acepção, não é possível sequer afirmar que as empresas envolvidas detenham efetivamente poder econômico. Muito menos que abusam dele.

79. Admita-se, todavia, apenas pelo aumento, e sem conceder, que se pudesse supor a existência efetiva de um poder econômico, adotando-se um conceito leigo, ou, pelo menos, bem diverso do que o que foi lançado acima, que apenas prestigiasse fatores como faturamento, investimento, participação no mercado ou capacidade empresarial. Ainda assim não haveria afronta ao ordenamento jurídico, porque não é o poder econômico que deve ser reprimido, mas, sim, o seu mau uso, seu emprego distorcido para finalidades não contempladas pela Constituição e pelas leis. Logo à frente se desenvolverá o tema do mercado e seu aspecto geográfico. Mas deve-se deixar destacado, desde agora, que em tempos de economia globalizada o poder econômico, no sentido obrangente empregado neste parágrafo, é uma necessidade imperativa imposta pela competição internacional.

80. Portanto, com tal conotação, o poder econômico não é um desvio a ser reprimido, mas um componente da economia moderna. Apenas quando perde a sintonia com a função social que deve desempenhar - dentre as quais a de promover valores constitucionais como o desenvolvimento nacional (art. 32, II), o emprego (art. 170, VIII) -- é que deve ser combatido. Com acuidade, José Afonso da Silva captou a evidência:

"A Constituiçāo reconhece a existência do poder econômico. Este não é, pois, condenado pelo regime constitucional. Não raro esse poder econômico é exercido de maneira antisocial. Cabe, então, ao Estado intervir para coibir o abuso."29

81. O contrato de associação aqui discutido, como se depreende de seus consideranda e de suas cláusulas, visa à economia de escala, que implica na diminuição do custo unitário pelo incremento da produção. Ainda que viesse a gerar, de fato, um poder econômico, estaria promovendo um fim legítimo. Confira-se, no particular, a lição de Sergio Varella Bruna:

"A diferenciação de produtos, as economias de escala e as concentraçóes de poder econômico são coisas normalmente presentes na realidade e não representain necessariamente um mal a ser combatido, senão muitas vezes um objetivo a alcançar, em prol da eficiência e da competitividade, mormente no campo internacional." ${ }^{30}$ (Grifo acrescentado)

82. Na mesma linha, veja-se Marcos Juruena Villela Souto:

"Como, pela via do planejamento, pode se optar por inserir o país na economia internacional de larga escala, tal fator deve ser considerado no julgamento dos concentrações econômicas e demais formas de aparente dominação de mercados locais. "31

29 José Afonso da Silva, Curso de direito constitucional positivo, 1995, p. 727. Veja-se, no mesmo sentido. Fábio Konder Comparato, Ordem de controle na sociedade anônima, 1976, p. 419.

30 Sérgio Varella Bruna, O poder econômico e a conceituaçấo do abuso em seu exercício. 1997, pp. 63 e 64 .

31 Marcos Juruena Villela Souto, Aspectos jurídicos do Planejamento Econômico, 1997, p. 179. A tese vincula a presença do Estado em atividades econômicas exploradas por empresas estatais à prévia definição do relevante interesse coletivo nas diretrizes do plano de desenvolvimento econômico exigido pelo art. 174 da Constituição, o que já se confirmou ao examinar que as várias mudanças no Programa de Reforma do Estado não afastaram a presença da PETROBRAS nos setores por ela ocupados. 
83. Em suma: não há. na espécie, poder econômico em sentido técnico. Admitida a existência de poder econômico, pelo emprego de uma definição aberta, constata-se que sua existência é legítima no seu objeto e na sua finalidade. Vale dizer: em nenhuma hipótese terá lugar, no caso vertente, o abuso do poder econômico.

84. Tampouco visa o contrato de associaçāo à dominação do mercado. Cabe, neste passo, aprofundar o conceito de mercado, cenário no qual será exercida a atividade econômica e, conseqüentemente, o poder. Mais que tudo, há necessidade de caracterizá-lo, à vista da circunstância de que existem vários mercados constitucionalmente reconhecidos. Não se pode desconsiderar, na atualidade, a existência, ao lado de um mercado nacional, de um mercado regional entre nações e de um outro mais amplo, internacional. ${ }^{32}$ De parte esta constatação, é de relevo assinalar, ainda, que a legislação ordinária se utiliza do conceito de "mercado relevante", não tão amplo a ponto de abranger todos os bens e serviços em circulação em um só mercado, nem tão restrito, a ponto de cada produto corresponder a um mercado. A Suprema Corte dos Estados Unidos assim o definiu:

"O mercado relevante é composto de produtos que razoavelmente podem ser substituídos um pelo outro quando empregados nos fins para os quais são produzidos - levando em consideração o preço, a finalidade $e a$ qualidade deles". 33

85. Inúmeras circunstâncias da vida moderna, que passam por fatores como mão-deobra, tecnologia, capitais e consumo, forçaram a formação de blocos regionais interestatais e, pouco à frente, a globalização da economia. Este é antes um dado da realidade do que uma opção política. Neste novo cenário intensificou-se, em todo o mundo, a pressão pela livre circulação de pessoas, serviços e bens, requisitos imperativos para os países que buscam inserção na comunidade internacional do comércio. E, inegavelmente, é através das economias de escala que se obtém a redução dos custos unitários dos produtos à medida em que se aumenta o volume da produçāo e a competitividade além fronteiras.

86. Antes mesmo da percepção mais formal desses fenômenos, já escrevera Geraldo de Camargo Vidigal:

"A tutela jurídica da competição, voltada contra os abusos de poder econômico e nascida dominantemente da análise macroeconônica do funcionamento dos mecanismos da concentraçāo empresarial, há de execitar-se, porém, de forma ajustar-se à preservação desses mecanismos, sempre que a eficiência produtiva social o impuser, pois freqüentemente devem eles receber tutela equivalente. para que os ganhos de eficiência fundados em economias de escala propiciem a competitividade dos produtores locais nos mercados externos e, mais do que isso, a competitividade de produtor local, nos próprios mercados internos, contra competiçāo provinda do exterior".$^{34}$ (Grifo acrescentado)

87. Os fenômenos da regionalização e da globalização têm como marco o Tratado de Roma, que criou a Comunidade Econômica Européia, e que dispôs sobre aspectos do direito concorrencial em seus arts. 85 e 86 . Tais normas repudiavam acordos e práticas concertadas que tivessem por objetivo impedir ou restringir a concorrência ou explorar de forma abusiva uma posiçāo dominante no mercado comum, de modo a afetar o comércio entre os Estados-membros. Referiam-se, portanto, a um mercado que não era doméstico, mas regional, compreendendo inúmeros Estados soberanos.

88. Este foi o precedente que influenciou,

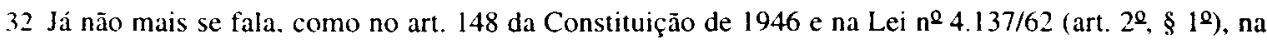
dominação de "mercados nacionais".

33 United States v. E. I. du Pont de Nemors \& Co.. 351 US 377 (1956) apud Benjamin M. Shieber, Abusos do Poder Econômico, 1966, p. 47.

$3+$ Geraldo de Camargo Vidigal, Teoria geral do direito econômico. 1977, p. 54. 
como é notório, a celebraçāo do Tratado de Assunçāo, que instituiu o Mercado Comum do Sul - MERCOSUL, cuja proposta de criaçāo, no caso do Brasil, tinha previsāo constitucional, inscrita no parágrafo único do art. 40:

"Art. 40.

Parágrafo único. A República Federativa do Brasil buscará a integração econômica, política, social e cultural dos povos da América Latina, visando à formação de uma comunidade latino-americana de nações."

89. O MERCOSUL implica, como dispõe 0 art. 1 do Tratado de Assunção, na "livrecirculação dos bens, serviços e fatores produtivos entre os países, através, entre outros, da eliminaçāo dos direitos alfandegários e restriçōes não-tarifárias à circulaçāo de mercadorias e de qualquer outra medida de efeito equivalente". Esta, portanto, a realidade enfrentada pelas empresas na atualidade: a ampliação das fronteiras comerciais, devido à formação de blocos econômicos, concertados por decisões políticas soberanas e, como tais, incontrastáveis. Suprimem-se, nesta mesma onda, os monopólios estatais, extinguem-se as reservas de mercado e a competiçāo se internacionaliza. Não há como examinar o contrato de associação aqui em questão sem considerar a premissa inafastável de que se está diante de um mercado internacional.

90. Poder-se-ia supor, a um primeiro lance de vista, tratar-se de um mercado internacional, mas regionalizado. A verdade, contudo, é que assim nāo é. Os fatos saltaram à frente, e dos blocos regionais passou-se a uma economia globalizada, independentemente de qualquer formalização. Em setores onde nāo impera a intervenção do Estado nem o protecionismo econômico - como é o caso da indústria petroquímica - o mercado é hoje internacional, globalizado. Diante de tal constatação, que nada tem de elaborada ou sutil, seria totalmente despropositada a crença de que o acordo entre a $O P P$ e a Petrobras pudesse se destinar à "dominação dos mercados".

91. Afastada a hipótese de dominação dos mercados, as duas outras tipificaçōes constitucionais do $\S 4^{\circ}$ do art. 173 do Texto Cons- titucional - "eliminação da concorrência" e "aumento arbitrário de lucros" — também não se aplicam à situação examinada. Confira-se.

92. A eliminação da concorrência nāo ocorrerá em nenhuma circunstância porque o contrato de associação celebrado não interfere com a capacidade de outras empresas se associarem, aí incluídas, diga-se de passagem, as empresas que atuam no mercado doméstico, diversas delas de grande porte. Cabe, neste passo, uma menção à cláusula sexta do ajuste, que estabelece uma preferência para os empreendimentos organizados nos termos do contrato de associação no que diz respeito ao acesso à matéria prima. Algumas observaçōes se impõem.

93. Em primeiro lugar, como já se deixou assentado, a Petrobras, sob o regime jurídico atualmente vigente, nāo atua como agente de fomento e nem mais exerce uma intervenção monopolística no mercado, e, sim, concorrencial, o que implica em dizer que seus empreendimentos devem almejar competitividade. Logo, nada impede que estabeleça uma parceria e ajuste prioridade no fornecimento de matérias-primas. Supridas as necessidades do empreendimento contratado, poderá ser atendida a eventual demanda que recaia sobre a Petrobras. O que se deve enfatizar é que, sendo uma empresa destina a concorrer no mercado (que, como visto, tem dimensão internacional), a sua prioridade é desenvolver seus empreendimentos (com ou sem parcerias). São esses negócios que implementarão o relevante interesse coletivo reconhecido por lei para a sua criação e manutenção como estatal. Naturalmente, se houver recusa injustificada da Petrobras em fornecer matéria prima para as demais empresas, aí sim se poderia caracterizar o abuso, em detrimento do competidor.

94. Mas é preciso ter em conta, no tocante a este tópico, que a Petrobras nāo é a única supridora potencial de matéria prima. Admitidas a produçāo e as importaçōes, em face do novo texto constitucional e da Lei 9.478/97, qualquer escassez de oferta ou elevação local de preços sujeitará os produtores nacionais à pressão competitiva de produtos estrangeiros, 
sempre lembrando que o mercado relevante. na espécie, é o internacional. O eventual poder de mercado é limitado pelo risco do ingresso de novos competidores. Nesse sentido é a lição de Nuno T. P. Carvalho:

"Quando uma fonte estrangeira do produto ou do serviço (efetiva ou potencial) inibe aquele monopolista de aumentar o preço, essa fonte é considerada como integrando o mercado relevante, e a sua participação no mercado será levada em conta para fins da determinaçāo da respectiva concentração." 35

95. Pelas mesmas razōes, e por outras que se acrescem, não há sentido em cogitar-se de aumento arbitrário de lucros. De plano cabe assinalar que o preço do petróleo e de seus derivados é ditado pelo mercado internacional. ${ }^{36}$ Nāo há, dessa forma, possibilidade de imposiçāo de preços excessivos. Ademais, sendo admitida a importaçāo, tanto de matéria prima como do produto acabado, não é possível o comportamento de redução da produção para forçar os preços para cima e aumentar o ganho.

96. Por tudo que foi visto, não há razoabilidade nem bom direito na tese de que o contrato de associação configuraria abuso de poder econômico, nem tampouco que visasse ele à dominaçāo dos mercados, à eliminação da concorrência e aumento arbitrário dos lucros. Ao revés, os objetivos almejados envolvem o ganho de uma economia de escala (reduzindo preços ao adquirente), a criação de uma associação nacional e o acesso à tecnologia.

97. Como se vê, ao contrário do insinuado, o ajuste é alinhado com normas e programas constitucionais e legais, a saber: é benéfico para o consumidor pela redução dos preços obtida pela economia de escala (CF, art. 170, V), cria uma associação brasileira apta à promoção do desenvolvimento nacional no setor (CF, art. 32, II) e aumenta a competitividade de agentes econômicos do mercado interno brasileiro no plano internacional (CF, art. 219), que é um dos objetivos da política energética nacional (Lei 9.478, de 6.08.97, art. 1, $\mathrm{XI}$ ).

\section{VI - CONCLUSŌES}

Ao fim desta exposiçāo, que se fez inevitavelmente longa, é possível compendiar as principais idéias desenvolvidas nas proposições seguintes:

1. A livre iniciativa é princípio fundamental do Estado brasileiro (CF, art. 12, IV), e tal circunstância deve condicionar todo o processo de interpretação constitucional, notadamente no tocante a temas afetos à ordem econômica. A intervenção do Estado em sentido contrastante com este princípio, inclusive sob a invocaçāo da competência para a disciplina da atividade econômica, somente será legítima nas hipóteses expressa e excepcionalmente previstas na Constituiçāo, mediante prova cabal e inequívoca da situação que a justifique, que não pode ser presumida.

II. A Petrobras é uma sociedade de economia mista exploradora de atividade econômica, e, como tal, uma pessoa jurídica de direito privado regida pela Lei das sociedades por ações. Sem embargo, como integrante da Administração Indireta, sujeita-se às normas constitucionais aplicáveis a entidades dessa natureza, que se concentram (a) na disciplina de suas relações com a pessoa jurídica instituidora e (b) nos mecanismos de controle de sua atuação, inclusive pelo Tribunal de Contas. Em suas relações com terceiros, todavia, notadamente com outras sociedades comerciais, submetem-se as sociedades de economia mista, e, ipso facto, a Petrobras, ao regime jurídico de direito privado, fundado na

35 Nuno T. P. Carvalho, As concentrações de empresas no Direito Antitruste, 1995, p. 140.

36 Ileana di Giovan, Derecho internacional economico, 1992, p. 26: “Si se compara el volumen del comercio mundial de granos y de azúcar - por no hablar de petroleo y otros minerales - con el volumen efectivamente negociado en el 'mercado libre', es decir, através de transaciones puntuales entre exportadores-productores e importadores-consumidores, se puede observar que el volumen de este último configura lo que denomina habitualmente como un mercado residual". 
liberdade de contratar e na autonomia da vontade, sendo perfeitamente legítimo que celebre um contrato de associação nos moldes do que foi aqui examinado.

III. A exploração da atividade econômica pela Petrobras é legítima, a luz da Constituição e da legislação ordinária. A Emenda Constitucional $\mathrm{n}^{\mathbf{2}}$ 9, ao dar nova redação ao $\S$ $1^{2}$ do art. 177, contemplou, expressamente, a atuação de empresas estatais no setor econômico do petróleo e seus derivados. E a Lei $8.031 / 90$, que criou o programa nacional de desestatização, excluiu de modo categórico a Petrobras do programa de privatização, em reconhecimento inequívoco de que atende ela. na realização de seu objeto, a relevante interesse coletivo, consoante o mandamento constitucional autorizativo da intervenção estatal (art. 173, § 19).

IV. Contrato de associação celebrado por sociedade de economia mista no desempenho de sua atividade-fim não se enquadra na previsāo constitucional de exigibilidade de licitação, que se aplica a obras, serviços, compras e alienaçōes (arts. 37, XXI), bem como à concessão ou permissão de serviços públicos (art. 175). A lei específica também não prevê a realização de licitação para este tipo de contrato, que se enquadra na espécie negocial consórcio (Lei 9.478/97, art. 63). Demais dis- to, é elemento essencial de sua celebração a presença de affectio societatis, cujo caráter subjetivo reforça o entendimento de que a licitação, procedimento objetivo por excelência, além de nāo exigível, é incompatível com o resultado visado.

V. Em sentido rigorosamente técnico de direito concorrencial, não há, na hipótese, poder econômico. Mesmo que se flexibilize o conceito para reconhecer a presença de poder econômico, sua simples existência não só não é incompatível com a Constituição como pode ser instrumento necessário de realização de fins constitucionais. O que se deve reprimir é o abuso do poder econômico, e isto claramente não ocorre no contrato examinado.

VI. O mercado petroquímico é global, os concorrentes são empresas de grande porte atuando no Brasil e em todo o mundo e os preços praticados são cotados internacionalmente. Logo, não há que se falar em dominação dos mercados, eliminação da concorrência e aumento arbitrário de lucros.

É como me parece.

Rio de Janeiro. 11 de dezembro de 1997.

\section{Luís Roberto Barroso}

Professor Titular de Direito Constitucional da Universidade do Estado do Rio de Janeiro; Master of Laws pela Yale Law School; Procurador do Estado do Rio de Janeiro. 